\title{
Histopathological Changes in Canine Allergic Contact Dermatitis Patch Test Reactions.
}

\section{A study on spontaneously hypersensitive dogs}

\author{
By Mads Krogsgaard Thomsen and Henrik Klem Thomsen
}

Dept. of Pharmacology

Leo Pharmaceutical Products, Ballerup and

Dept. of Pathology, Bispebjerg Hospital, Copenhagen, Denmark.

\begin{abstract}
Thomsen, M. K. and H. K. Thomsen: Histopathological changes in canine allergic contact dermatitis patch test reactions. A study on spontaneously hypersensitive dogs. Acta vet. scand. 1989, 30, 379-384. - The histopathology of allergic patch test reactions in dogs with spontaneous allergic contact dermatitis (ACD) was investigated. Epidermal necrosis was present in half of the biopsies and neutrophilic granulocytes were present within epidermis in these biopsies as well as in some of the biopsies without necrosis. Spongiosis was only occasionally observed.

Dermal infiltration with neutrophilic granulocytes and oedema was found in all biopsies while the number of lymphocytes was small.

The results may indicate a different secretion of or responsiveness towards cytokines in canine ACD compared to ACD in man where epidermal necrosis is not a characteristic feature and where the predominant inflammatory cell is the lymphocyte.

It is anticipated that histopathological investigation of patch test reactions in dogs will not be helpful in discriminating between allergic and toxic patch test reactions.
\end{abstract}

dog; neutrophil; chemotaxis.

\section{Introduction}

Contact dermatitis is a skin disease which may be allergic, irritant or photomediated. This paper deals with allergic contact dermatitis (ACD) which is recognized in man, dog, horse, pig, chicken and other species (Polak 1977).

In the dog, ACD accounts for $1 \%$ of all dermatoses (Gaafar \& Krawiec 1974), but constitutes $5 \%$ of hospitalized skin cases (Nesbitt \& Schmitz 1977, Thomsen \& Kristensen 1986). No genetic predisposition has been verified (Nesbitt 1983). Clinically, the eczema is evident in thin-haired contact areas (Walton 1971). In natural cases of ACD, hi- stopathology is inconclusive, showing unspecific subacute or chronic dermatitis changes (Nesbitt \& Schmitz 1977). Partly for this reason, a number of experimental studies have been caried out in the dog using dinitrochlorobenzene (DNCB) as sensitizer (Krawiec \& Gaafar 1975). The histopathological findings at the experimental test sites have been variable. Since closed patch test has been considered impractical in the dog, no histopathological investigations on biopsies from patch test sites in allergologically diagnosed spontaneous ACD in the dog have been published. It is the objective of this study to examine the histopathological changes 
in this situation, accomplished by taking biopsies from positive reactions obtained with the European standard series of contact allergens.

\section{Materials and methods}

14 biopsies from 11 allergic dogs are included in the study. Clinical data concerning the implicated patients are available elsewhere (Thomsen \& Kristensen 1986) and from Table 1. Dogs that fulfilled the criteria for a tentative diagnosis of ACD were tested with a standardized closed patch test kit from Chemotechnique Diagnostics AB (Malmo, Sweden). Prior to this, the dorsum was gently clipped and cleansed. The test strips with $1 / 2 \mathrm{~cm}$ of test substance applied per patch were applied and the position of each patch was secured through generous use of adhesive.

The patches were removed after $48 \mathrm{~h}$ and a reading performed half an hour later and 24 $\mathrm{h}$ later. Reaction sites that exhibited erythema and perhaps oedema were only considered to represent $A C D$ if they extended beyond the test site and had not faded signi- ficantly by 72 h (Thomsen \& Kristensen 1986). Contraindications for carrying out the patch test were seborrhea and recent or present dermatitis in the test area.

A full-thickness $6 \mathrm{~mm}$ punch biopsy specimen was taken at $72 \mathrm{~h}$ from the center of the inflammatory site after subcutaneous infiltration with $1 / 2 \%$ lidocaine. Only test reactions of at least $>>+<<$ intensity (Thomsen \& Kristensen 1986) were biopsied. The biopsies were processed via conventional techniques and embedded in Paraplast (R). Stepsections were cut from each block and stained with haematoxylin-eosin, van Gieson-Hansen and PAS.

\section{Results}

Macroscopically, the patch test lesions appeared as erythematous, slightly elevated areas. The elevated skin had a consistency in accordance with the presence of oedema.

\section{Epidermis}

Epidermal changes were present in all biopsies. Necrosis was present in 7 of the 14 biopsies (Fig. 1). This change ranged from mini-

Table 1. Clinical data on the 11 dogs included in the study: Positive reactions were elicited by 11 different contact allergens. Three dogs had localized symptoms and 3 owners possessed at least 1 more dog that did not suffer from ACD.

\begin{tabular}{llllcc}
\hline Breed & Sex & Age & Pos. reactions & Localized & Other dogs \\
\hline Alsatian & M $^{*}$ & $1^{\wedge}$ & Thiuram mix & + & + \\
Beagle & M & 3 & Formaldehyde & + & - \\
Alsatian & M & 8 & Chrome, Cobalt, & - & - \\
& & & Nikkel, Quinoline & & \\
Labrador & M & 3 & Cobalt & - & - \\
Am. Cocker & F & 3 & Wood tar & - & - \\
Boxer & F & 1 & Carbamix & + & + \\
Alsatian & F & 2 & Carbamix & - & - \\
Alsatian & M & 3 & Epoxy resin & - & - \\
Alsatian & M & 5 & Fragrance mix & - & - \\
Spr. span. & M & 2 & Wool alcohols & - & - \\
Mix breed & F & 8 & Carbamix & - & + \\
\hline
\end{tabular}

*: M(ale), F(emale) ^ : at onset of symptoms 
mal and focal to widespread and marked. Neutrophilic granulocytes were always present in such areas. Neutrophilic granulocytes were also present in 4 biopsies without necrosis, but only focally and in small numbers. Slight, focal parakeratosis was found in most biopsies while spongiotic foci were only occasionally encountered. Lymphocytes were not observed within epidermis.

\section{Dermis}

Oedema and neutrophilic granulocytes were present in the superficial half of dermis in all biopsies, but the degree varied from mild to marked. There was a tendency that marked degrees were found in cases with extensive epidermal necrosis. A sparse number of lymfocytes and histiocytes was also present in the superficial part of dermis. Follicular accumulations of neutrophilic granulocytes were observed in a few biopsies, but otherwise hair follicles appeared normal. The superficial vessels were dilated, but otherwise the vessels appeared unaltered.

\section{Subcutis}

No changes were found in the subcutaneous tissue.

\section{Discussion}

In the present study the changes varied markedly quantitatively from biopsy to biopsy, while they were qualitatively very much alike. It is therefore probable that the observed changes reflect the same biological reaction pattern in the tissue.

The histopathology of the ACD patch test reaction in spontaneously hypersensitive dogs has not formerly been studied, but investigations of spontaneously occurring ACD have revealed non-specific changes where the inflammatory infiltrate sometimes is predominantly lymfocytic and sometimes with dominans of neutrophilic granulocytes
(Nesbitt \& Schmitz 1977). DNCB has been used in experimental studies to compare $A C D$ and ICD in dogs as well as in other animals and in man. In dogs, one study (Krawiec \& Gaafar 1975) indicates that a dermal lymfocytic infiltrate was present in cases considered ACD while epidermal necrosis and an inflammatory infiltrate predominantly of neutrophilic granulocytes was found in ICD. The same reaction pattern has been found in guinea pigs (Karl et al. 1974, Medenica \& Rostenberg 1971) while attempts at sensitizing cats (Scott 1980), mice (Vredevoe 1964) - and dogs in one study (Schultz \& Adams 1978) - led to a cellular infiltrate consisting primarily of neutrophilic granulocytes. In man, identical reaction patterns with a predominantly lymphocytic response was found in both ACD and irritant contact dermatitis (ICD) and only quantitative differences with a different dose response was present (Hartman et al. 1976, Nater \& Hoedemaeker 1976, Willis et al. 1986). At least in some species, eg. the dog, discrimination between experimental and clinical studies must be made. DNCB sensitization in these species is difficult, and when present must be considered to be weak, with only minor epidermal damage - and perhaps other morphological differences as a consequense. The cause of ACD is a delayed type hypersensitivity reaction in which lympho- and cytokines secreted by lymphocytes and other cell types, respectively, are the cause of inflammation (Baer \& Turk 1983). Species differences in ACD histopathology may be explained - as Cohen (1976) has done - on the basis of differences with regard to these factors. Briefly, it was suggested that the predominantly neutrophilic granulocytic infiltrate observed in murine ACD was due to extensive lymphocyte secretion of the lymphokine; leukocyte migration inhibition factor (LIF), which arrests neutrophilic granulocytes at 
the inflammatory site. LIF is but one of the factors with effect on the motility of the neutrophilic granulocyte, and the general statement (Schultz \& Adams 1978) that dogs do not suffer from the typical cell-mediated immunological diseases seen in man, highlights the relevance of a discussion of the lympho/ cytokine profile in the dog. If the keratinocyte necrosis observed in some of the biopsy specimens is a primary change due to lymphokine activity from the lymphocytes initiating the inflammation, some consequences are clear. First of all, varying degrees of sublethal, ultrastructural keratinocyte damage can be envisaged also in specimens not exhibiting necrosis by light microscopic examination. Sublethal noxious stimuli to keratinocytes are considered to promote secretion of »epidermal cell-derived thymocyteactivating factor" (ETAF) (Luger et al. 1981). ETAF is identical to interleukin 1 (IL1) (Luger et al. 1983) which possesses chemotactic activity towards neutrophilic granulocytes (Cybulsky et al. 1986). Thus, an infiltrate with neutrophilic granulocytes would be expected and was found in all the present biopsies, including the biopsies without evidence of necrosis. In canine DNCB studies, epidermal damage may have been too weak to attract neutrophilic granulocytes.

When comparing the lymphocytic infiltrate present in human ACD to the neutrophilic granulocytic infiltrate in canine $A C D$, some further explanations for the observed species differences are possible. It is well known that human and dog neutrophilic granulocytes vary qualitatively and quantitatively in their receptors for various chemoattractants (Redl et al. 1983). For instance, the potency of IL-1 with respect to neutrophil chemotaxis has not been established in the dog and compared to man.

Furthermore, the migration inhibitory acti- vity (LIF) of lymphocyte cultures in the two species have not been compared. Thus, either enhanced attraction of neutrophilic granulocytes to the site of inflammation in the dog, or reduced emigration from the site, could account for the observed delayed hypersensitivity reaction in the dog. Finally, doubt has been raised about the capability of human lymphocytes to secrete a neutrophil chemotactic factor present in other species implying that lymphocytes involved in cellmediated immunity in man may primarily be capable of attracting mononuclear cells (Czarnetzki et al. 1983).

It might be argued that the described cases are primary irritant and not allergic reactions. The following clinical and allergological observations, however, render this possibility highly unlikely. In 3 cases (Table 1), more than 1 dog was kept by the owner but in each case, only 1 suffered from dermatitis. Moreover, the studied dogs generally did not benefit from a stay away from the owner, in agreement with the observation that contact allergens - but not irritants - are difficult to eliminate in canine ACD. Three dogs had localized ACD (Table 1) attributable to a hapten that was identified by patch testing and subsequently removed from the environment followed by regression of the clinical signs within a few days.

If the patch test reactions were primary irritant in nature, the following patch test-related observations would be unlikely. Eleven different contact allergens (Table 1) were involved, indicating that irritant reactions caused by one or a few test allergens were not the cause of the histopathologic findings. The vehicle used for the test series was soft paraffin (except formaldehyde which was aqueous) which is known for its low potential for irritant reactions (Mendelow \& Baillie 1985). Regarding the erythema at the test site, this generally extended beyond the test 
$M . K$ Thomsen \& $H K$. Thomsen: Histopathological changes in canine allergic contact dermatitis patch test reactions. A study on spontaneously hypersensitive dogs.

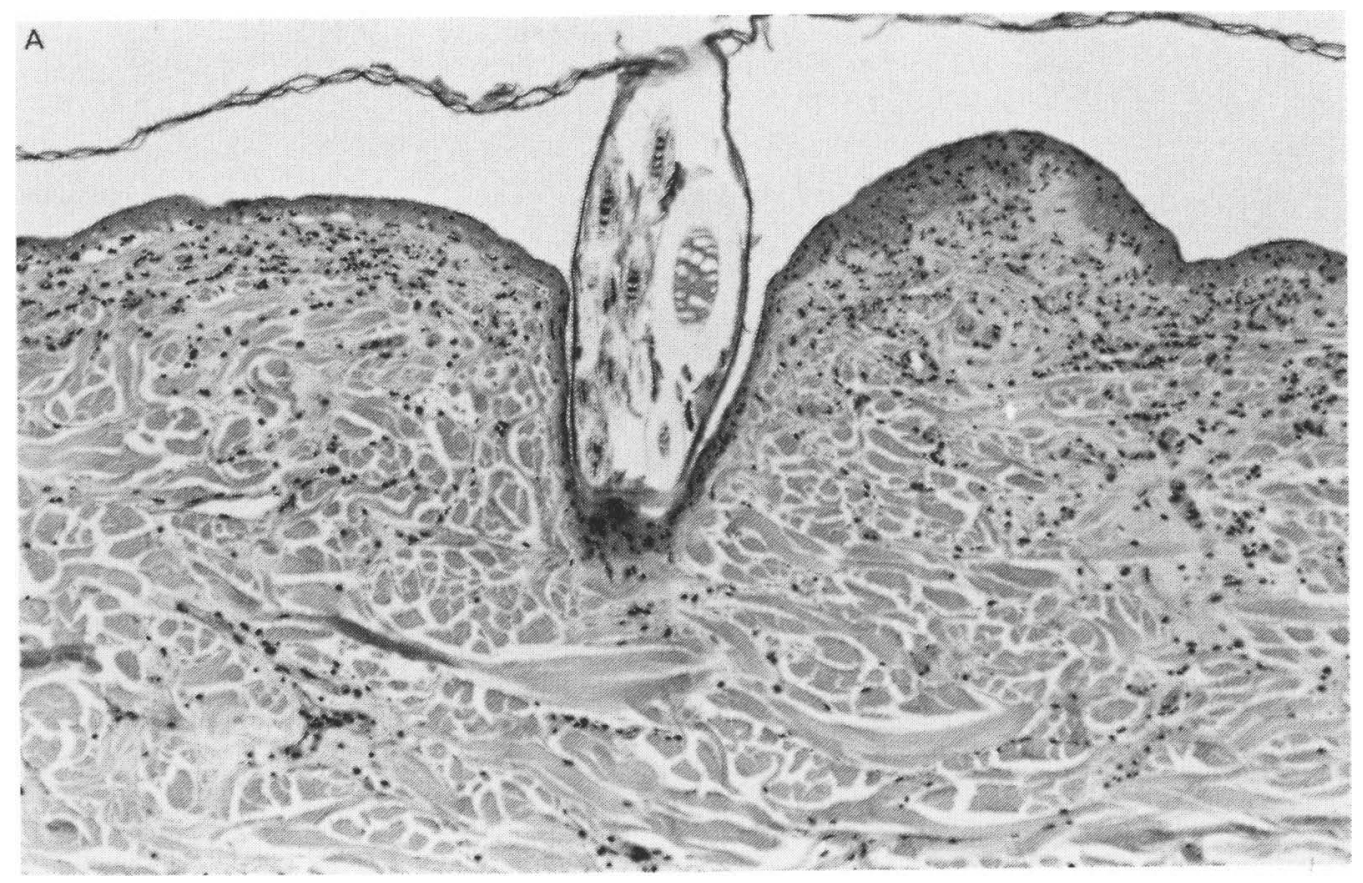

Figure 1A. Canine skin from patch test site. Epidermis to the right of the follicular infundibulum appears almost normal, while it is thinned with effaced rete ridges to the left. A sparse inflammatory infiltrate is present in the upper dermis. H-E $\times 130$.

B

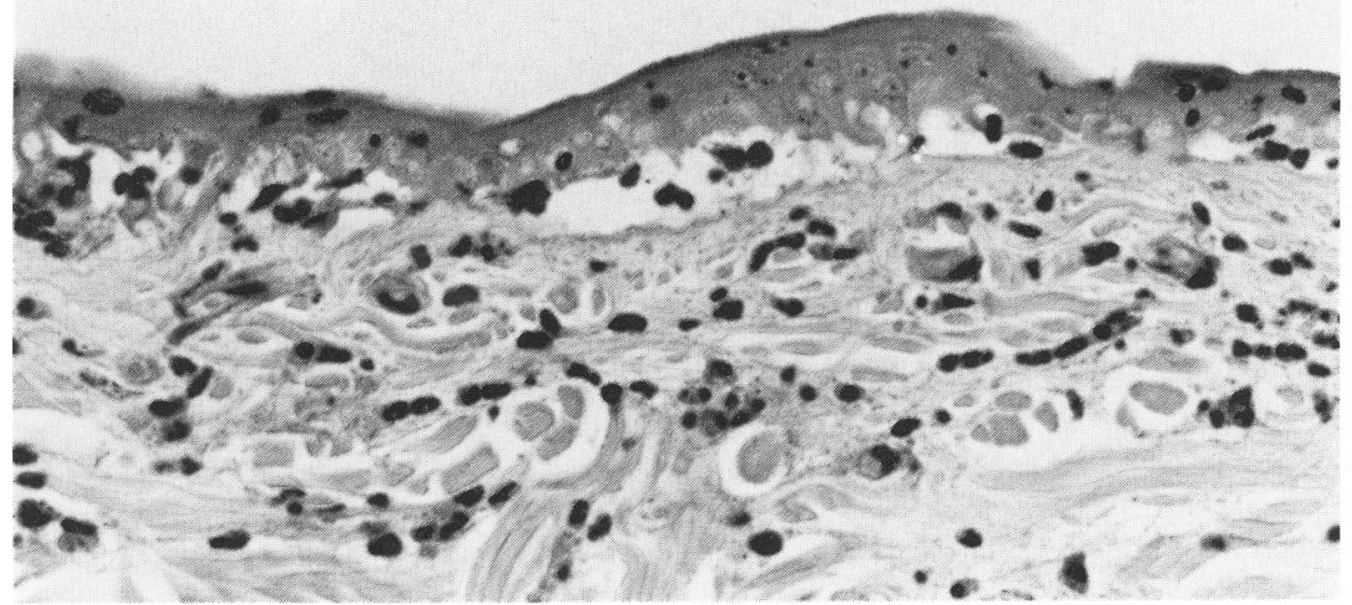

Figure 1B. Higher magnitication of the lett part of A. Epıdermıs appears necrotic with loss of nuclei and blurring of cytoplasmic details. Neutrophilic granulocytes are present both within the necrotic epithelium and in the subjacent dermis. H-E $\times 525$. 

site, and in 2 instances peaked in intensity a day after patch removal indicating an allergic patch test reaction (Muller et al. 1989).

\section{Conclusion}

The value of a histopathological examination to verify the allergic nature of patch test lesions in dogs is probably limited. Even though ICD patch tests have not been investigated in the present study, it is not likely that the morphology of such lesions will differ considerably from the described morphology of ACD patch lesions.

\section{Acknowledgements}

The inspiration and allergological expertise provided for by Dr. Flemming Kristensen, Dept. of Small Animal Diseases, Royal Veterinary and Agricultural University, is gratefully acknowledged by the authors.

\section{References}

Baer RL, Turk JL: Delayed skin reactions. In: Biochemistry and Physiology of the Skin, Ed. Goldsmith LA. Oxford University Press, New York 1983, 921-937.

Cohen, S: Cell mediated immunity and the inflammatory system. Human Pathol. 1976, 7, 29-264.

Cybulsky, MI, Colditz, IG, Movat, HC: The role of interleukin-1 in neutrophil leukocyte emigration induced by endotoxin. Amer. J. Pathol. 1986, 124, 67-72.

Czarnetzki BM, Kownatzki E, Dierich M, Frei PC: Chemotaxis: basic aspects of methodology, mechanisms and pathology. Arch. Dermatol. Res. 1983, 275, 359-364.

Gaafar SM, Krawlec DR: Chemical sensitizers and contact dermatitis. J. Amer. Anim. Hosp. Assoc. 1974, 10, 133-138.

Hartman A, Hoedemaeker PJ, Nater JP: Histological aspects of DNCB sensitiation and challenge tests. Br. J. Dermatol. 1976, 94, 407-416.

Karl H, Burg G, Braun-Falco O: Quantitative and qualitative dynamics of the epidermal and cellular inflammatory reaction in primary toxic and allergic dinitrochlorobenzene contact dermatitis in guinea pigs. Arch. Dermatol. Forsch. 1974, 249, 207-226.
Krawlec DR, Gaafar SM: A comparative study of allergic and primary irritant contact dermatitis with dinitrochlorobenzene (DNCB) in dogs. J. Invest. Dermatol. 1975, 65, 248-251.

Luger TA, Stadler BM, Katz SI, Openheim JJ: Epidermal cell (keratinocyte)-derived thymocyte-activating factor (ETAF). J. Immunol. 1981, 127, 1493-1498.

Luger TA, Charon JA, Oppenheim JJ: Heterogeneity of chemoattractant activity for neutrophils and mononuclear cells of ETAF and IL-1. J. Immunol. 1983, 81, 187-192.

Medenica M, Rostenberg A: A comparative light and electron microscopic study of primary irritant contact dermatitis and allergic contact dermatitis. J. Invest. Dermatol. 1971, 56, 259-271.

Mendelow AY, Baillie AJ: Pharmaceutical considerations in patch testing for contact dermatitis. Pharmacy Int. 1985, 6, 230-234.

Muller GH, Kirk RW, Scott DW: Small Animal Dermatology, WB Saunders Company, Philadelphia 1989, 464-469.

Nater JP, Hoedemaeker PJ: Histological differences between irritant and allergic patch test reactions in man. Contact Dermatitis 1976, 2, 247-253.

Nesbitt GH: Canine and Feline Dermatology: a systematic approach. Lea \& Feibiger, Philadelphia 1983 , pp. 55-57.

Nesbitt GH, Schmitz JA: Contact dermatitis in the dog: a review of 35 cases. J. Amer. Anim. Hosp. Assoc. 1977, 13, 155-163.

Nobreus N, Magnusson B, Leandoer L, Attstrom: Induction of Dinitrochlorobenzene contact sensitivity in dogs. Monogr. Allergy 1974, 8, 100109.

Polak L: Immunological aspects of contact sensitivity. In: Dermatotoxicology and Pharmacology, eds. Marzulli FN, Maibach HI. Hemisphere Publishing Corporation, Washington 1977, pp. 225-287.

Redl H, Flynn PJ, Lamche H, Schiesser A, Schlag G, Hammerschmidt DE: Aggregation, chemotaxis, and chemiluminescence of canine granulocytes. Inflammation 1983, 7, 67-80.

Schultz RD, Adams LS: Detection of cellular immune function. Vet. Clin. North Amer. 1978, 8, 742-753. 
Scott DW: Feline dermatology 1900-1978: a monograph. J. Amer. Anim. Hosp. Assoc. 1980, 16, 331-459.

Thomsen MK, Kristensen F: Contact dermatitis in the dog. A review and a clinical study. Nord. Vet. Med. 1986, 38, 129-147.

Vredevoe $D L$ : The production and transfer of immune reactions to bovine serum albumin in isogeneic and allogeneic mice. II Dermal reactivity. J. Immunol. 1964, 92, 717-723.

Walton GS: Hypersensitivity responses to contact allergens. Adv. Vet. Sci. Comp. Med. 1971, 15, 224-229.

Willis CM, Young E, Brandon DR, Wilkinson JO: Immunopathological and ultrastructural findings in human allergic and irritant contact dermatitis. Br. J. Dermatol. 1986, 115, 305-316.

\begin{abstract}
Sammendrag
Histopatologiske fund i lappeprøve biopsier fra hunde med allergisk kontakt-eksem.

Histopatologisk undersøgelse af biopsier fra positive lappeprøver blev udført på 11 hunde med spontant, allergisk kontakteksem (AKE).Epidermal nekrose var til stede i halvdelen af biopsierne, og et epidermalt infiltrat af neutrofile granulocyter sås i disse samt i nogle biopsier uden nekrose. Spongiose optrådte kun lejlighedsvis. Dermal infiltration med neutrofile granulocyter samt ødem sås i alle biopsier, hvorimod lymfocyter var fåtallige. Fundene indicerer muligvis en anden sekretorisk profil for, eller cellulært respons på, cytokiner involveret i AKE hos hunden i forhold til hos mennesket, hvor epidermal nekrose ikke er karakteristisk, og den primære inflammationscelle er lymfocyten. Det konkluderes, at histopatologisk undersøgelse af lappeprøvebiopsier ikke vil tillade entydig diskrimination mellem allergiske og toksiske lappeprøvereaktioner hos hunden.
\end{abstract}

(Recelved October 20, 1988; accepted December 14, 1988).

Reprints may be requested from: M. K. Thomsen, Dept. of Pharmacology, Leo Pharmaceuticral Products, DK-2750 Ballerup, Denmark. 